$\begin{gathered}\text { EPiC Series in Built Environment } \\ \text { Volume 2, 2021, Pages 432-440 }\end{gathered}$
ASC 2021. 57th Annual Associated Schools
of Construction International Conference

\title{
An Exploratory Study on CM Syllabi Components
}

\author{
Ben Farrow, Ph.D., Tom Leathem, Ph.D., Amna Salman, Ph.D. Student \\ Auburn University \\ Auburn, AL
}

The course syllabus is a staple document in virtually every higher education classroom. Studies suggest that given appropriate attention to contents, the syllabus has opportunity to elevate student engagement and performance in a class. However, research on syllabi components in construction management $(\mathrm{CM})$ is minimal to date. This paper presents an introductory exploration into the inclusion of syllabi components within CM that informed a larger body of research currently ongoing. Couse syllabi from 34, 4-year CM programs were evaluated for the presence of 26 specific components. These results were compared to a previous study of 350 syllabi in higher education and current recommended practice by selected teaching and learning centers to determine the areas where CM syllabi exceed or fall short of other disciplines. CM syllabi exceeded other disciplines within higher education in most categories. Details related to course assignments, instructor contact information, events specific to $\mathrm{CM}$, and motivation of learning tactics were the key areas where $\mathrm{CM}$ syllabi had potential to enhance educational effectiveness within the $\mathrm{CM}$ discipline.

Key Words: Construction Education, Syllabus, Policy, Grading

\section{Introduction}

In recent years, $\mathrm{CM}$ education has experienced new commitments to the student experience and learning. Recent trends and shifts have led to enhanced expectations in the classroom. The American Council of Construction Education's (ACCE's) shift to student learning outcomes has focused the educational experience on the skills and knowledge the student is expected students in CM than ever before, and industry is fully engaged in creating meaningful internships. Renewed focus has been placed on creating a positive experience for underrepresented populations. And, a focus on active learning in the construction classroom through experiences like service learning, lab experiences, and competition teams have been a focus. As an instructor in this environment where learning and development is a priority, one has the opportunity to consider the student's educational needs, interests, and purposes as one begins to develop the curriculum of a given class.

The syllabus is often the first item distributed in most $\mathrm{CM}$ classes and perhaps the first opportunity to address educational needs, interest, and purpose. Studies indicate most faculty embrace the importance of the syllabus as it sets policy and expectations. However, there are differences in the areas of what a syllabus should do and how it should be used. Some syllabi are extremely detailed and uniform; others may be inconsistent and serve multiple purposes and audiences. Beyond the required 
information, an opportunity exists for instructors to use the syllabus as a learning tool that can reinforce the "intentions, roles, attitudes, and strategies" used to "promote active purposeful, effective learning" (Grunert, 1997, p. 3). Purposeful development of a syllabus with focus on these elements has been shown to improve student performance. However, syllabi can lack the components necessary to achieve this. While the use of learning management systems has been suggested as one tool to help remedy this issue, literature on them indicates otherwise (Jaschik \& Lederman, 2014; Kasim \& Khalid, 2016). Research exists on syllabi in higher education. However, the published research to date on the components of CM syllabi is limited (.......).

This study served as the introductory work that was part of a larger research endeavor to further understanding about the constructs of CM syllabi. Frequencies of CM syllabi components were evaluated against other areas of higher education in an effort to determine differences that may exist, as well as highlight common areas of occurrence. Furthering this area of knowledge provides opportunity to improve understanding about the strengths and weaknesses in CM higher education and serve to advance educational effectiveness of the discipline. This exploratory study provides a basis for additional research on syllabi elements in connection with student expectations and learning.

\section{Literature Review}

Syllabi can serve a variety of functions in an effort to support and challenge students. Parkes and Harris (2002) stated the basic purposes more succinctly as a contract, a permanent record, and a resource for student learning. They argued that the student has an opportunity to determine if they wish to remain in the course, schedule their time, and review their progress along the way in the class. The permanent record aspect of the syllabus protects the instructor, university, and students (Habanek, 2005). Often used in accreditation, the permanent record also allows reviewers to examine a course within the curriculum (Slattery \& Carlson, 2005). Davis (2009) suggests a comprehensive course syllabus should include twelve basic elements:

1. Basic course information

2. Course Description

3. Course Materials

4. Requirements

5. Policies
6. Course Schedule

7. Student Resources

8. Statement on Accommodation

9. Assessment of learning
10. Rights and Responsibilities

11. Safety and Emergency Preparedness

12. Instructor Disclaimer

Parkes and Harris also argue that the syllabus is an effective tool for students to develop skills to be self-regulated learners when the proper components are included (2002). Other items in syllabi may be used to enhance learning in the class by addressing the logic/ organization of the class, identifying instructional priorities, and providing a blueprint for the learning in the class (Grunert, 1997). Some researchers have noted that the syllabus not only informs students about the course but also conveys the personality of the instructor, creates a first impression of the instructor and his/her attitudes toward teaching (Harnish \& Bridges, 2011; McKeachie, 1986). Bain (2004) introduced the promising syllabus which focused on "beyond the classroom" learning. Such an approach shifts the course from "instructor focused" to "learner focused" and considers three primary components. These components are "What this course promises you."; "How will you fulfil these promises?"; and "Here begins a conversation about how the teacher and student will best come to understand the nature and progress of the student's learning". Similarly, a recent study on psychology syllabi suggested that learner-centered syllabi emphasize elements of community, student autonomy, and clear evaluation/assessment procedures toward identified learning outcomes (Richmond, Morgan, Slattery, Mitchell, \& Cooper, 2019). Cullen and Harris (2009) describe these three categories as "community", 
"power and control", and "evaluation/assessment" in their syllabus evaluation rubric. Grunert (1997, pp. 14-19) identified sixteen functions of a syllabus that help support increased student engagement:

1. Establishes an early point of contact and connection between student and instructor

2. Helps set the tone for the course

3. Describes instructor's beliefs about educationa purposes

4. Acquaints students with the logistics

5. Contains collected handouts

6. Defines student responsibilities for successful course work

7. Describes active learning

8. Helps students to assess their readiness
9. Sets the course in a broader context for learnin

10. Provides a conceptual framework

11. Describes available learning resources

12. Communicates the role of technology

13. Can expand to provide difficult to obtain reading materials

14. Can improve the effectiveness of note taking

15. Can include material that supports learning outside the classroom

16. Can serve as a learning contract

Multiple studies agree that syllabi focused on the learner (learner-centered) yield higher student evaluations of instructor, course, and syllabus and sets the stage for a high level of learning within the classroom (Harnish \& Bridges, 2011; Richmond, Slattery, Morgan, Mitchell, \& Becknell, 2016). One study indicates the most important syllabus components included assignment information, grading information, attendance information, and instructor contact information (Garavalia, Hummel, Wiley, $\&$ Huitt, 1999). Another study identified assignment, grading, attendance information, and required work as items students focused on when reviewing a syllabus (Becker \& Calhoon, 1999). Other studies indicate students were more engaged in a class if the syllabus promoted: student involvement in creating course policies (DiClementi \& Handelsman, 2005), greater detail about course assignment and grading requirements (Saville, Zinn, Brown, \& Marchuk, 2010), and demonstrating concern for student learning (Richmond et al., 2016). As compared to students, instructors indicated the most essential elements of the syllabus to include "communication mechanism", "course plan for students", a "contract" and a "planning tool for the instructor" - components more (Fink, 2012).These cited differences in teacher-centered vs. student-centered syllabi are summarized in Table 1.

Table 1

Summary of Teacher-Centered vs. Student-Centered Syllabus

\begin{tabular}{|c|c|c|}
\hline Syllabus Element & Teacher-Centered & Student-Centered \\
\hline $\begin{array}{l}\text { Professor Information (Name, } \\
\text { contact info, office hours) }\end{array}$ & $\begin{array}{l}\text { Transmitted from instructor } \\
\text { with limited options }\end{array}$ & $\begin{array}{l}\text { Multiple options with student } \\
\text { input }\end{array}$ \\
\hline $\begin{array}{l}\text { Course Information } \\
\text { (Description, location, texts, } \\
\text { topics, course calendar) }\end{array}$ & $\begin{array}{l}\text { Emphasizes teacher as } \\
\text { leader/authority with syllabus } \\
\text { as planning tool for instructor }\end{array}$ & $\begin{array}{l}\text { Presents teacher as } \\
\text { facilitator/partner in learning } \\
\text { with detailed assignment } \\
\text { information }\end{array}$ \\
\hline $\begin{array}{l}\text { Grading Information (policy, } \\
\text { scale, assignments) }\end{array}$ & $\begin{array}{l}\text { Focus on grades and } \\
\text { punishment }\end{array}$ & $\begin{array}{l}\text { Ongoing feedback with } \\
\text { multiple assessment } \\
\text { approaches focused on } \\
\text { curiosity, student autonomy, } \\
\text { community }\end{array}$ \\
\hline $\begin{array}{c}\text { Policy Information } \\
\text { (attendance, late work, honor } \\
\text { code, disability) }\end{array}$ & $\begin{array}{l}\text { Fosters competitive, } \\
\text { individualistic approach }\end{array}$ & $\begin{array}{l}\text { Fosters collaborative, } \\
\text { supportive environment }\end{array}$ \\
\hline
\end{tabular}


The research suggests that if course syllabi were constructed to be more learner-centered instead of teacher-centered, this could positively influence student's attitudes towards the class and instructor which promote increased motivation. Understanding more about the typical constructs of CM syllabi could provide insight about potential opportunities to enhance learning within the discipline. The information presented in this paper, which is part of a larger research study, looks at the components included in a small sample of CM syllabi.

\section{Method}

The study was delimited to a sample population of baccalaureate CM programs accredited by the American Council for Construction Education (ACCE). ACCE includes an accessible population of 76 schools. Syllabi were selected on a per school basis since ACCE's accreditation standardizes some of the syllabi elements including areas of objectives, content, resources, and grading information (Document 102B: Preparation of the Self-Evaluation Study Bachelor's Degree, 2019). Based on this understanding, the researchers used the assumption - recognizing this is a limitation - that one syllabus collected from a program would provide a representative sample for that entire program. To achieve results generalizable to the population, a sample size of 36 syllabi was determined using a $p=.10$, and a $90 \%$ confidence interval.

A total of 34 syllabi from different construction programs across the U.S. were collected and evaluated (Table 2). Syllabi were collected from open-access portals including the Associated Schools of Construction - Construction Expertise Exchange hosted by Procore (10 syllabi), university websites ( 3 syllabi) and faculty solicitation ( 21 syllabi). Only syllabi from face-to-face classes were included. Since only 34 syllabi were collected, the study is just short of the required 36 to provide a sample at a statistically significance level $p=.10, C I=90 \%$.

Table 2

Descriptive Statistics of Construction Program Syllabi Evaluated

\begin{tabular}{|c|c|c|c|c|c|c|c|}
\hline \multicolumn{2}{|c|}{ US Region } & \multicolumn{2}{|c|}{ College } & \multicolumn{2}{|c|}{ Course Type } & \multicolumn{2}{|c|}{ Syllabus Term } \\
\hline Northeast & 2 & $\begin{array}{l}\text { Architecture } \\
\text { \& Design }\end{array}$ & 7 & Precon/PM & 10 & $\begin{array}{l}\text { Not } \\
\text { Indicated }\end{array}$ & 7 \\
\hline Midwest & 10 & $\begin{array}{l}\text { Engineering } \\
\& \\
\text { Technology }\end{array}$ & 20 & $\begin{array}{l}\text { Estimating / } \\
\text { Scheduling }\end{array}$ & 8 & $\begin{array}{l}\text { Spring } \\
2018\end{array}$ & 1 \\
\hline Southeast & 6 & Business & 2 & $\mathrm{VDC} / \mathrm{Tech}$ & 1 & $\begin{array}{l}\text { Fall } \\
2018\end{array}$ & 4 \\
\hline Southwest & 6 & Other & 5 & Fundamentals & 12 & $\begin{array}{l}\text { Spring } \\
2019\end{array}$ & 12 \\
\hline Northwest & 10 & & & $\begin{array}{l}\text { Law/Pro } \\
\text { Practice }\end{array}$ & 3 & $\begin{array}{l}\text { Fall } \\
2019\end{array}$ & 10 \\
\hline
\end{tabular}

Note: "Fundamentals" includes structures, safety, materials \& methods, MEP systems, and documents.

Each of the 34 syllabi were visually evaluated based on the 26 components reported by Doolittle and Siudzinski (2010). Recognizing the age of the Doolittle study, syllabi were also evaluated based on component recommendations for syllabi published by six teaching and learning centers that operate at schools in the top 35 US universities as defined by US News \& World Report (2019). Syllabi 
components included four broad categories: professor information, course information, grading information, and policy information. The researchers independently conducted visual evaluation of each syllabus for inclusion or absence of noted components and recorded their findings in an excel spreadsheet. Their individual findings were then combined into a single spreadsheet for final analysis. No attempt was made to evaluate the efficacy or quality of the syllabus components.

Syllabi were evaluated using what was printed on the syllabus only and did not include additional details that may have been included in an accompanying learning management system such as Canvas or Blackboard. Of the syllabi studied, 17 had notes in the syllabi that referenced some type of learning management system that supported the class. The authors recognize that additional detail included in any learning management system could alter the results of this study. However, literature on the most common uses of learning management systems (LMS) indicates faculty use them as a repository for course documents - including syllabi (Jaschik \& Lederman, 2014) and as a communication tool for course announcements and discussions (Kasim \& Khalid, 2016). The majority of faculty do not take advantage of the more advanced elements of an LMS to improve course learning outcomes (Dahlstrom, Brooks, \& Bichsel, 2014).

\section{Results}

Results were obtained for each of the three research questions: 1) What syllabus components are included by $\mathrm{CM}$ faculty members within their syllabi? 2) What syllabus components are often omitted from CM syllabi? 3) What differences, if any exists, between syllabi in other disciplines and CM syllabi?

\section{Comparison of 26 Components as Identified by Doolittle and Siudzinski}

Results indicate that CM syllabi have a higher overall inclusion rate when compared to the higher education syllabi study (Figure 1). However, CM syllabi have a decreasing trend similar to that of the higher education study.

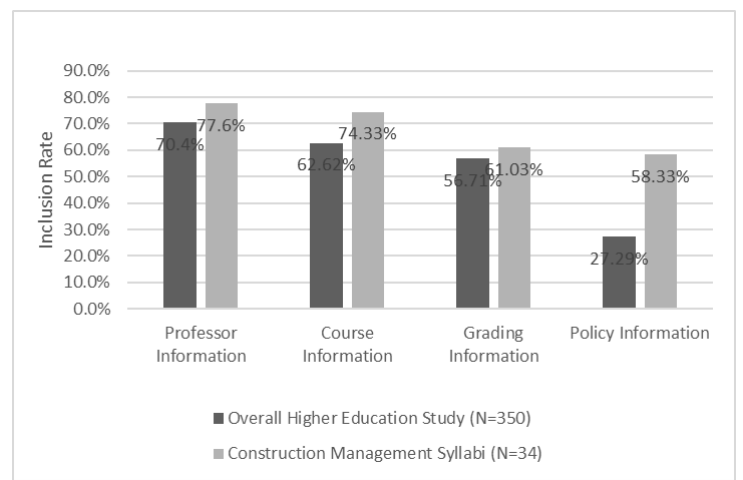

Figure 1. Syllabus Inclusion Rates by Syllabus Category

Components of syllabi are shown in Table 3. Three of the five most frequently occurring items occurred in both overall higher education and CM syllabi. 
Table 3

Components Included in Higher Education Syllabi

\begin{tabular}{|c|c|c|c|c|}
\hline Category & $\begin{array}{c}\text { Frequency in } \\
\text { Overall Higher } \\
\text { Education } \\
\text { Study }(\mathbf{N}=\mathbf{3 5 0}) \\
\end{array}$ & $\begin{array}{c}\text { Frequency in } \\
\text { CM Syllabi } \\
(\mathbf{N}=34)\end{array}$ & $\begin{array}{c}\text { Rank in } \\
\text { Overall Higher } \\
\text { Education } \\
\text { Study } \\
\end{array}$ & $\begin{array}{c}\text { Rank in CM } \\
\text { Syllabi }\end{array}$ \\
\hline \multicolumn{5}{|c|}{ Professor Information } \\
\hline Professor Name & 303 & 30 & 4 & 8 \\
\hline Office Location & 231 & 29 & 9 & 10 \\
\hline Office Hours & 210 & 19 & 12 & 19 \\
\hline Office Phone & 240 & 24 & 8 & 14 \\
\hline Professor e-mail & 248 & 30 & 7 & 8 \\
\hline \multicolumn{5}{|c|}{ Course Information } \\
\hline Course Name & 335 & 34 & 1 & 1 \\
\hline Course Number & 327 & 34 & 2 & 1 \\
\hline $\begin{array}{c}\text { Course } \\
\text { Description }\end{array}$ & 222 & 32 & 10 & 6 \\
\hline Course Location & 141 & 23 & 20 & 16 \\
\hline Course Time & 173 & 22 & 16 & 17 \\
\hline $\begin{array}{c}\text { Course } \\
\text { Goals/Objectives }\end{array}$ & 214 & 33 & 11 & 3 \\
\hline $\begin{array}{c}\text { Course Required } \\
\text { Texts } \\
\text { Course }\end{array}$ & 312 & 31 & 3 & 7 \\
\hline $\begin{array}{l}\text { Supplemental } \\
\text { Readings }\end{array}$ & 62 & 11 & 25 & 23 \\
\hline Course Topics & 260 & 24 & 6 & 14 \\
\hline Course Calendar & 209 & 22 & 13 & 17 \\
\hline Course Due Dates & 156 & 12 & 18 & 22 \\
\hline \multicolumn{5}{|c|}{ Grading Information } \\
\hline Grading Policy & 283 & 33 & 5 & 3 \\
\hline Grading Scale & 162 & 28 & 17 & 11 \\
\hline $\begin{array}{l}\text { Assignment } \\
\text { Names }\end{array}$ & 204 & 15 & 14 & 20 \\
\hline $\begin{array}{l}\text { Assignment } \\
\text { Description }\end{array}$ & 145 & 7 & 19 & 26 \\
\hline \multicolumn{5}{|c|}{ Policy Information } \\
\hline Attendance Policy & 194 & 26 & 15 & 12 \\
\hline Late Work Policy & 88 & 15 & 22 & 20 \\
\hline $\begin{array}{l}\text { Missed Work } \\
\text { Policy }\end{array}$ & 70 & 11 & 24 & 23 \\
\hline $\begin{array}{l}\text { Honor Code } \\
\text { Policy }\end{array}$ & 122 & 33 & 21 & 3 \\
\hline Disability Policy & 83 & 26 & 23 & 12 \\
\hline $\begin{array}{c}\text { Student Support } \\
\text { Services }\end{array}$ & 16 & 8 & 26 & 25 \\
\hline
\end{tabular}

On the basis of student benefit, both studies indicate strong performance in the area of instructor accessibility, with the weakest areas being in policies on missed and late work. Information inclusion 
related to course assignments and grading had a broad range for inclusion rank. The box plot in figure 2 illustrates the spread of inclusion rank for the assignment and grading information.

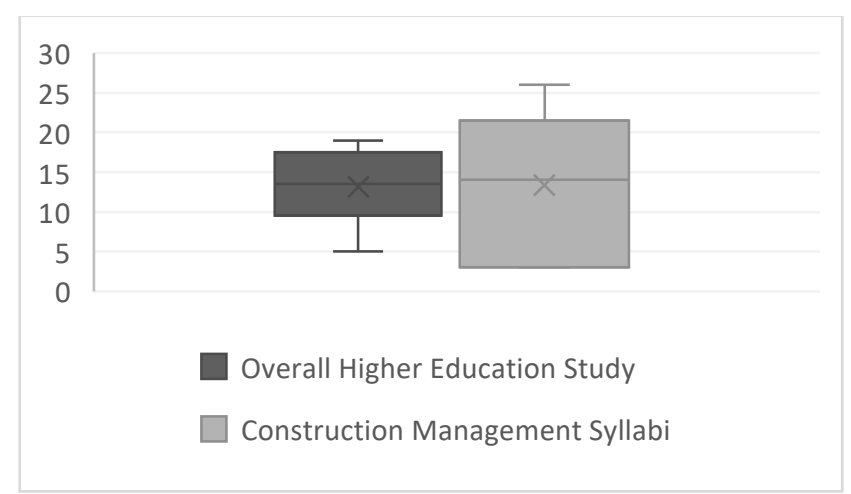

Figure 2. Syllabi inclusion ranking for assignment and grading information

Comparison of Syllabi Recommendations from Teaching and Learning Centers

Teaching and learning centers were considered at the following campuses: Cornell University, Princeton University, University of California-Berkley, University of Florida, University of Michigan, and Vanderbilt University. Results indicate a wider variation in syllabi requirements. While the topics included by those learning centers do not match exactly those used in the study by Doolittle and Siudzinski, all of the recommendations include detailed faculty information and schedule of assignments. In addition, three of the centers studied, commonly noted three items: instructor methods, prerequisites, and course websites.

\section{Analysis and Conclusions}

This study evaluated components of CM syllabi in comparison to other higher education disciplines and previous studies identifying syllabus elements beneficial to student learning. Overall, CM syllabi were shown to be more inclusive in the four major areas of professor information, course information, grading information, and policy information than the comparative 2007 study. However, the CM syllabi could be improved in the area of assessment information, and procedures supporting a studentcentered learning approach. The results suggest that syllabi in the CM discipline do a better job of providing information important to influencing student engagement and enthusiasm in a course as compared to higher education in general. However, opportunities may exist to further elevate student interest and engagement by employing the recommendations listed in table 4 below.

The authors acknowledge that the results and subsequent conclusions are not without limitation. First, this study compared CM syllabi against results from a 2010 study. Recognizing that this study is nearly 10 -years old, it is conceivable that syllabi components from other higher education sectors have changed since then. An attempt to temper this issue has been made by including current recommended syllabi practices from high ranking US institutions. Such inclusions suggest that developing opportunities for syllabi are in the area of student-centered learning, and further research is needed in this area within CM. Second, the sample population for CM syllabi was delimited to ACCE accredited programs on the basis that one syllabus from a program would be representative within that program. It is possible syllabi within a single program differ by course and faculty, and this should be studied further. As well, this study did not evaluate how the incorporation of learning 
management systems may affect results. Other opportunities include evaluating the components of a syllabus valued by CM students and faculty. Despite the identified limitations, the study provides thought provoking information about possible strengths and weaknesses in CM higher education syllabi, and serves to advance educational effectiveness of the discipline.

Table 4

Overall Conclusions from Exploratory Study of Syllabi

\begin{tabular}{|c|c|c|c|c|}
\hline $\begin{array}{c}\text { CM } \\
\text { Result }\end{array}$ & $\begin{array}{c}\text { Relative to } \\
\text { Doolittle Study }\end{array}$ & $\begin{array}{c}\text { Relative to } \\
\text { Teaching and } \\
\text { Learning Center } \\
\text { Recommendations }\end{array}$ & $\begin{array}{l}\text { Relative to } \\
\text { Student- } \\
\text { Centered } \\
\text { Syllabi }\end{array}$ & Recommendation \\
\hline $\begin{array}{l}\text { Relatively low } \\
\text { in assignment } \\
\text { related } \\
\text { information }\end{array}$ & $\begin{array}{l}\text { Overall HE had } \\
\text { frequency in } \\
\text { middle third; } \\
\text { CM had } \\
\text { frequency in } \\
\text { bottom third. }\end{array}$ & $\begin{array}{l}\text { All recommended } \\
\text { full schedule of } \\
\text { assignments }\end{array}$ & $\begin{array}{c}\text { Inclusion of } \\
\text { assignment } \\
\text { details promote } \\
\text { student freedom } \\
\text { and clear } \\
\text { evaluation } \\
\text { procedures } \\
\text { toward learning }\end{array}$ & $\begin{array}{c}\text { Increase } \\
\text { assignment details } \\
\text { in syllabi } \\
\text { including actual } \\
\text { assignment, due } \\
\text { date, and grading } \\
\text { rubrics }\end{array}$ \\
\hline $\begin{array}{c}\text { Strong in } \\
\text { instructor } \\
\text { access/contact } \\
\text { options, course } \\
\text { goals/ } \\
\text { objective, and } \\
\text { grading policy }\end{array}$ & $\begin{array}{l}\text { Overall HE had } \\
\text { all of these areas } \\
\text { in top third; CM } \\
\text { had contact } \\
\text { options in top } \\
\text { half and } \\
\text { goals/objectives/ } \\
\text { grading policy in } \\
\text { top quartile }\end{array}$ & $\begin{array}{l}\text { All had some focus } \\
\text { on contact options; } \\
\text { Goals/objectives } \\
\text { and grading policy } \\
\text { were addressed or } \\
\text { alluded to in most } \\
\text { recommendations. }\end{array}$ & $\begin{array}{l}\text { All are items } \\
\text { important in } \\
\text { student-centered } \\
\text { environment } \\
\text { Adds focus on } \\
\text { class websites } \\
\text { and teaching } \\
\text { assistants in } \\
\text { process }\end{array}$ & $\begin{array}{c}\text { Consider } \\
\text { additional contact } \\
\text { options for } \\
\text { instructors } \\
\text { including multiple } \\
\text { contact modes } \\
\text { including social } \\
\text { media/websites }\end{array}$ \\
\hline $\begin{array}{l}\text { Options to } \\
\text { expand syllabi } \\
\text { for CM } \\
\text { specific issues } \\
\text { exists }\end{array}$ & $\begin{array}{l}\text { Not included in } \\
2007 \text { study }\end{array}$ & $\begin{array}{l}\text { Adds field trips and } \\
\text { safety related items }\end{array}$ & $\begin{array}{l}\text { Motivates } \\
\text { curiosity for } \\
\text { learning and } \\
\text { meaningfulness } \\
\text { of class; Builds } \\
\text { student } \\
\text { engagement }\end{array}$ & $\begin{array}{l}\text { Find opportunities } \\
\text { to motivate } \\
\text { learning and build } \\
\text { CM culture by } \\
\text { including safety } \\
\text { and field trips }\end{array}$ \\
\hline $\begin{array}{l}\text { Instructor } \\
\text { methods }\end{array}$ & $\begin{array}{l}\text { Not included in } \\
2007 \text { study }\end{array}$ & $\begin{array}{l}\text { Adds opportunity } \\
\text { to detail }\end{array}$ & $\begin{array}{l}\text { Motivates active } \\
\text { learning; sets } \\
\text { expectation for } \\
\text { rigor: helps } \\
\text { students learn } \\
\end{array}$ & $\begin{array}{c}\text { Include details of } \\
\text { variety of methods } \\
\text { in which learning } \\
\text { will occur }\end{array}$ \\
\hline
\end{tabular}

\section{References}

Bain, K. (2004). What the best college teachers do. Boston, MA: Harvard University Press.

Becker, A. H., \& Calhoon, S. K. (1999). What introductory psychology students attend to on a course syllabus. Teaching of Psychology, 26(1), 6-11. 
Cullen, R., \& Harris, M. (2009). Assessing learner-centredness through course syllabi, Assessment \& Evaluation in Higher Education. 34, 1(115-125). https://doi.org/10.1080/02602930801956018

Dahlstrom, E., Brooks, D. C., \& Bichsel, J. (2014). The Current Ecosystem of Learning Management Systems in Education: Student, Faculty, and IT Perspectives [Research report]. Retrieved from http://www.educause.edu/ecar

Davis, B. G. (2009). Tools for teaching.

DiClementi, J. D., \& Handelsman, M. M. (2005). Empowering students: Class-generated course rules. Teaching of Psychology, 32, 18-21. https://doi.org/10.1207/s15328023top3201_4

Document 102B: Preparation of the Self-Evaluation Study Bachelor's Degree. (2019). Retrieved from https://www.acce-hq.org/resources/forms-documents/

Doolittle, P. E., \& Siudzinski, R. A. (2010). Recommended syllabus components: What do higher education faculty include in their syllabi? Journal on Excellence in College Teaching, 21(3).

Doolittle, P., \& Lusk, D. L. (2007). The effects of institutional classification and gender inclusion of syllabus components. Journal of Scholarship of Teaching and Learning, 7, 62-78.

Garavalia, L. S., Hummel, J. H., Wiley, L. P., \& Huitt, W. G. (1999). Constructing the course syllabus: Faculty and student perceptions of important syllabus components. Journal on Excellence in College Teaching, 10(1), 5-21.

Grunert, J. (1997). The course syllabus: A learning-centered approach. Boston, MA: Anker Publishing Company, Inc.

Habanek, D. (2005). An examination of the integrity of the syllabus. College Teaching, 53(2), 62-64.

Harnish, R. J., \& Bridges, K. R. (2011). Effect of syllabus tone: Students' perceptions of instructor and course. Social Psychology Education.

Jaschik, S., \& Lederman, D. (2014). The 2014 Inside Higher Ed Survey of faculty Attitudes on Technology: A Study by Gallup and Inside Higher Ed. Retrieved from https://www.insidehighered.com/news/survey/online-ed-skepticism-and-self-sufficiencysurveyfaculty-views-technology

Kasim, N. N. M., \& Khalid, F. (2016). Choosing the right learning management system for higher education: A systematic review. International Journal of Emerging Technologies in Learning, 11(6), 55-61.

McKeachie, W. J. (1986). Teaching tips: A guidebook for the beginning college teacher (8th ed.). Lexington, MA: D.C. Heath.

Parkes, J., \& Harris, M. (2002). The Purpose of a Syllabus. Semantic Scholar, 50(2), 55-61.

Richmond, A. S., Morgan, R. K., Slattery, J. M., Mitchell, N. G., \& Cooper, A. G. (2019). Project Syllabus: An Exploratory Study of Learner-Centered Syllabi. Teaching of Psychology. 46(1), 6-15.

Richmond, A. S., Slattery, J., Morgan, R. K., Mitchell, N., \& Becknell, J. (2016). Can a learnercentered syllabus change student's perceptions of student-professor rapport and master teacher behaviors? Scholarship of Teaching and Learning in Psychology, 2, 159-168. https://doi.org/10.1037/st10000066

Saville, B. K., Zinn, T. E., Brown, A. R., \& Marchuk, K. A. (2010). Syllabus detail and students' perceptions of teacher effectiveness. Teaching of Psychology, 37, 186-189. https://doi.org/10.1080/00986283.2010.488523

Slattery, J., \& Carlson, J. (2005). Preparing an effective syllabus: Current best practices. College Teaching, 53(4), 159-164.

Smith, M., \& Razzouk, N. (1993). Improving classroom communication: The case of a course syllabus. Journal of Education for Business, 68(4), 215-221. 